\title{
A Positive Kveim Reaction in a Case of
}

\section{Leprosy}

\author{
S. G. B R OWNE, M.D., F.R.C.P., F.R.C.S. D.T.M. \\ Leprosy Service Research Unit, Uzuakoli, Eastern Nigeria
}

The intriguing question of the relation subsisting between sarcoidosis and leprosy, raised long ago by Rabello (1936) and Reenstierna (1937), has been revived recently both by researches into sarcoidosis (Scadding, I96o; D'Arcy Hart et al., I 964; and many others) and by the symposium-by-correspondence on sarcoidosis and leprosy reported in the International Journal of Leprosy (1962).

The Kveim reaction is now generally held to be specific and positive in the great majority of histologically proved subjects of sarcoidosis. It was at one time suspected that false positives did not occur (Brit. med. J., I960), but they have been reported in granulomatous disease of known causation (Daniel and Schneider, I962), and also in leprosy (Kooij, r 958; Dugois et al., I 960 ) and referred to by other workers (James and Jopling, I96ı ; Brit. med. J., I 964). Kooij ( 1964 ) suggests that leprosy may be misdiagnosed clinically as sarcoidosis by clinicians insufficiently acquainted with the varied cutaneous manifestations of leprosy. The converse also is possible, and leprologists may be missing cases of sarcoidosis because of their preoccupation with their specialty.

All the patients receiving treatment at Uzuakoli Leprosy Settlement have been periodically reviewed with this possibility in mind. Eleven patients have been intensively studied because their cutaneous leprosy lesions bore some resemblance to the various lesions of sarcoidosis associated with the names of Besnier, Boeck, Schaumann, Darier, Roussy and others, and hence might be diagnosed as sarcoidosis if encountered in Caucasians living in countries where leprosy is not endemic.

All the I I patients were deeply pigmented Nigerians, healthy apart from leprosy. Nine were males, and two females; four were children, and seven adults.

\section{Bacterioscopic findings}

In seven patients, no Myco. leprae could be found on prolonged searching of material obtained by the slit-smear method from the lesion itself or from the ear-lobes and nasal mucosa. In three patients with clinically similar but multiple lesions, Myco. leprae were found at all these sites, and one patient had a high Bacterial Index, with globi at all sites.

\section{The lesions}

The commonest lesion was a slightly raised plaque involving the nose and perhaps extending to adjacent areas of the face - the cheeks, upper lip, and centre of the forehead. The limits might be well-defined or might merge imperceptibly into the surrounding normal skin. In colour, the lesion was reddish or violaceous, or slategrey. The surface was generally smooth and shiny, but not of the greasy appearance associated with diffuse infiltrative lepromatous leprosy. Sensory loss was minimal. Such lesions were also found on the forearms, deltoid region, scapular region, etc.

\section{Mantoux reaction}

The Mantoux reaction (I/Iooo PPD) was negative in four patients, slightly positive in four and moderately positive in three.

\section{Lepromin reaction}

The early (Fernández) and late (Mitsuda) reactions were comparable in each case. They were completely negative in three cases classified as lepromatous or borderline, moderately positive in two classified as borderline on the tuberculoid side, and highly positive in the remaining six. 


\section{Kveim reaction}

O. $5 \mathrm{ml}$. of Kveim antigen (kindly supplied by the Standards Laboratory of the Medical Research Council, London) was injected intracutaneously into the extensor surface of the arm just above the elbow. The site of injection was examined daily for the first three days, and then at weekly intervals.

Slight infiltration and local tenderness developed at the site during the first few days in eight patients, but disappeared more or less rapidly. In two patients, a papule developed which disappeared by the seventh day in the first case, but which persisted till the seventh week in the other. One patient, a boy of 12 years, who had slight transient tenderness of the site of inoculation, developed a palpable nodule during the sixth week which subsequently increased in size.

Under local anaesthesia, an elliptical portion of skin and subcutaneous tissue (including the site injected) was removed from each patient during the seventh week, and dispatched in formal saline solution for histological examination.

Dr A. H. T. Robb-Smith, of the Radcliffe Infirmiry, Oxford, kindly processed and examined the specimens of tissue. He reported that all were negative except that from the boy referred to above, which showed a 'typical positive reaction'. In three others, there was a very slight cellular reaction.

\section{IS C USS I O N}

The patient whose Kveim test was positive had been under treatment with dapsone for I 8 months. A few weeks before he was admitted to the Settlement, many small, slightly raised, violaceous lesions had made their appearance on the face, trunk and limbs: some were plaque like or dome-shaped, and scaly. Other lesions appeared, which were hypopigmented and contained a ring of papules within a flat hypopigmented advancing halo. This case bears some clinical resemblance to that reported by Flock and Mailloux (1958), in which similar lesions occurred after BCG inoculation.

All the main peripheral nerve trunks were slightly enlarged and slightly harder than normal. A blister had recently appeared on the left great toe, giving place to an indolent ulcer.
All bacteriological examinations (of lesions, ear-lobes, and nasal mucosa) were negative. The Mantoux test was negative. The Fernández and Mitsuda reactions were strongly positive, the site ulcerating. The lepromin test had been performed but once before: it has been suggested that repeated microvaccinations with mycobacterial antigen might provoke a positive, lepromin - and possibly a positive Kveim reaction. The patient had not received $\mathrm{BCG}$ vaccination, which also might induce a positive Kveim reaction (Ellman and Andrews, I959; Hoffbrand, i963).

The serum proteins were found to be $9.5 \mathrm{~g}$. per Iooml.: albumin $4.8 \mathrm{~g}$., and globulin $4.7 \mathrm{~g}$.

The patient continued to improve under standard treatment with dapsone, and was eventually discharged symptom-free. At no time did he develop any abnormalities in the eyes, glands, or chest. No suggestion of erythema nodosum appeared: one patient in four with sarcoidosis is likely to have erythema nodosum at some time (Greenberg et al., I 964), but patients with abacillary borderline leprosy never experience erythema nodosum leprosum. No essential difference could be detected, clinically or pathologically, between this patient and the others in the group in whom the Kveim reaction was negative.

To those familiar with leprosy and its typical accompanying peripheral neuropathy, the diagnosis of this case is not in doubt. Local changes in the main peripheral nerve trunks of the limbs, principally at the well-known sites of predilection, are generally regarded as pathognomonic of leprosy, but attention should be drawn to the case of sarcoidosis reported by Garrod (1964) in which trigeminal neuralgia and transient peripheral neuritis were observed.

Histological examination of skin lesions discloses round-celled infiltration around and within the terminal nerve fibrils in the dermis - a picture not observed in sarcoidosis - and focalization around the skin adnexa superficially, with a more diffuse granulomatous infiltrate situated in the deeper layers.

The pathological interest of the positive Kveim reaction in a single case in the series lies in the 'specific' alteration of tissue reactivity associated in some way with a hyperergic response to a paucibacillary leprosy infection. This response was shown clinically by the sudden 
appearance of multiple skin lesions of characteristic aspect. The significance of the positive Kveim reaction must remain a matter for conjecture.

The hope is expressed that the reporting of this isolated case may stimulate further research into the relation between leprosy and sarcoidosis.

\section{S UM M A R Y}

A patient with leprosy is reported in which the Kveim reaction was 'typically positive'. In ten other patients whose leprosy lesions also bore some resemblance to cutaneous lesions of sarcoidosis, the Kveim reaction was negative.

\section{A GKNOWLEDGEMENTS}

My thanks are due to Dr Patricia Bradstreet for supplying the Kveim antigen used; to Dr A. H. T. Robb-Smith for his help in reporting on the histology of the specimens sent to him; and to Dr S. O. Egwuatu, Chief Medical Officer, Ministry of Health, Eastern Nigeria, for permission to publish this article.

\section{RE FERE NCES}

Brit. med. 7. 2, I 750, 1960.

Brit. med. 7., 1, 791, 1964.

daniel, т. m. and schneider, g. w., Amer Rev. resp. Dis., 86, 97, i 962 .

Dugois, P., mounier, R. and gagnaire, J., Bull. Soc. franc.

Derm. Syph., 67, 8 г 2, I 960.

ellman, P. and Andrews. L. G., Brit. med.J., I, I 433, I 959. Flock, H., and mailloux, m., Bull. Soc. Path. exot., 51, 353 , I 958 .

Garrod, o., Proc. R. Soc. Med., 57, I 75, I 964.

GREENBERG, G., FEIZI, T., JAMES, D. G., and BIRD, R., Lancet, 2, I 3 I 3 , I 964 .

HART, D'ARCY, P., Mitchell, D. N., and SUTHERLAND, I., Brit. med. 7., 1, 795, 1964 .

hOFFBRAND, B. I., Brit. med. 7., 1, 658, 1963.

Int. 7. Leprosy, 30, 346, I 962.

James, D. G., AND JOpling, w. H., 7. trop. Med. Hyg., 64, 42, I 96 I.

коOІ J, R. Dermatologica, г16, I ; г1 7, 336, г 958.

кoolJ, R., Brit. 7. Derm., 76, 203, 1964.

rabello, J. R., Ann. Derm Syph., 7, 57 I, i 963.

reenstierna, J., Int. 7. Leprosy, 5, 433, I 937

scADDing, J. G., Brit. med. J., 2, I6 I 7, (1 960). 